\title{
Survey for the Occurrence of Powdery Mildew and It's Effect of Weather Factors on Severity of Powdery Mildew in Guntur District
}

\author{
Tulasi Korra* and V. Manoj Kumar \\ Department of Plant Pathology, Acharya. N. Ranga. Agricultural University, Bapatla, LAM, \\ Guntur, India \\ *Corresponding author
}

\begin{abstract}
A B S T R A C T
A roving survey was undertaken on the incidence and severity of powdery mildew disease

Keywords

Blackgarm, Erysiphe polygoni, Survey, Disease severity, Weather factors

Article Info

Accepted:

10 October 2018

Available Online:

10 November 2018 during rabi 2015-16 in Guntur district of Andhra Pradesh. Disease incidence and severity of powdery mildew were surveyed in villages of Tadikonda, Veticherukuru, Pedanandipadu and Kakumanu mandals of Guntur district. Incidence was ranged from $13.69 \%$ (Pedanandipadu mandal) to $87.01 \%$ (Tadikonda mandal) incidence and severity were ranged from 11.61 (Kakumanu mandal) to $88.08 \%$ (Tadikonda mandal), respectively. Correlation studies with weather parameters and crop age on powdery mildew disease severity revealed that positive correlation of disease was recorded with crop age and maximum temperature. Multiple regression analysis yielded seven distinct equations with $R^{2}$ values ranging from 0.991 to 0.412 ( $\left.\mathrm{P}<0.05\right)$. However, the best-fit equation was obtained in maximum temperature, wind speed, $\mathrm{RH}(8.30 \mathrm{am})$, Minimum temperature as independent variables showed 86.6 per cent role of tested independent variables on powdery mildew severity.
\end{abstract}

\section{Introduction}

Black gram (Vigna mungo (L.) Hepper) is a stable crop originated from central Asia and commonly cultivated in South Asia. Vigna mungo is also grown for forage crop, often used as dry season intercrop in rice or wheat, cover crop, and green manure (Göhl, 1982; Jansen, 2006). It prefers on loamy soils or black vertisols, well-drained soils with a $\mathrm{pH}$ 67 (Arora et al., 1989 and Baligar et al., 2007). It can withstand acidic soils if lime and gypsum (down to $\mathrm{pH} 4.5$ ) are added to the soil and sensitive to alkaline and saline soils (Sharma et al., 2011; Baligar et al., 2007). It is drought-tolerant and thus suitable for semiarid areas (Arora et al., 1989). Globally it accounts for over and above $40 \%$ of total legume seeds traded (CRN India, 2011).

Pod husks of Vigna mungo are an excellent substitute to rice bran as a feed for Artemia sp. regarding for survival, growth, production of nauplii and fecundity (Yoganandhan et al., 2000). In India it is a third important pulse crop cultivated in an area of $2.29 \mathrm{M}$ ha with $1.96 \mathrm{M} \mathrm{t}$ production and $500 \mathrm{~kg} \mathrm{ha}^{-1}$ productivity (Department of Agriculture and Cooperation, Government of India, 2014). In India, major urdbean growing areas are 
Andhra Pradesh, Gujarat, Karnataka, Madhya Pradesh, Maharashtra, Orissa, Punjab, Rajasthan, Sikkim, Tamil Nadu and Uttar Pradesh and Andhra Pradesh (A.P). In Kharif, it is grown in $0.25 \mathrm{Lakh}$ ha, producing 0.17 Lakh $\mathrm{t}$ with a productivity of $676 \mathrm{~kg} \mathrm{ha}^{-1}$. In $R a b i$, it occupies 4.29 Lakh ha, producing 3.39 Lakh $\mathrm{t}$ with a productivity of $790 \mathrm{~kg} \mathrm{ha}^{-1}$ (Department of Agriculture and Co-operation, Government of A.P. 2014). The crop is of special significance in A.P as it fits well in rice-pulse cropping system as a relay crop particularly in Krishna -Godavari and North Coastal zones. As per graminae, Vigna mungo plant genome sequence (http://archive.gramene.org/db) the genomes (7) and genes (1) literature (107) and ontology (72). Powdery mildew (Erysiphe polygoni) De Condolle (1802) described many species of the genus. Powdery mildew caused by Erysiphe polygoni D C a wide spread plant diseases that are conspicuous by their superficial white mycelia and powder-like conidia (Yarwood, 1957; Kiss and Szentivanyi, 2001). Current classification Fungi, Dikarya, Ascomycota, Pezizomycotina, Leotiomycetes, Leotiomycetidae, Erysiphales, Erysiphaceae, Erysiphe polygoni. Obligate synonyms; Ischnochaeta polygoni (DC.) and Microsphaera polygoni (DC.) Facultative synonymns: Alphitomorpha communis Wallr, Alphitomorpha horridula Wallr, Erysiphe communis var. leguminosarum Link, Erysiphe communis var. ranunculacearum Link. (www.mycobank.org.in).

Blackgram abides from biotic stress due to fungal, bacterial and viral diseases resulting in heavy yield losses (Nene, 1972). Powdery mildew reported as a serious problem in all areas of rice-based cropping systems of the country (Abbaiah, 1993) causing considerable yield loss every year due to the reduction in photosynthetic activity and physiological changes (Legapsi et al., 1978). Although the disease was reported to cause considerable loss, information on its prevalence particularly after the advent of the survey and epidemiological factors influencing the disease development.

\section{Materials and Methods}

The present investigation was carried out during rabi 2015-16, Agricultural College Farm and Department of Plant Pathology, Agricultural College, Bapatla, Guntur District. Geographically the Agricultural College Farm, Bapatla is situated at an altitude of $5 \mathrm{~m}$ above the mean sea level and at $80^{\circ} 30^{\prime}$ E Longitude and $15^{\circ} 54^{\prime} \mathrm{N}$ Latitude and seven $\mathrm{km}$ away from the coast of Bay of Bengal.

\section{Survey for the Incidence and severity of Powdery mildew disease of Urdbean}

Survey was conducted during 2015-16 rabi season in major urdbean growing mandals of Guntur district, Andhra Pradesh. Four mandals were chosen based on statistics of preceeding year where the crop concentration was more. Based on the information, in each mandal two villages and in each village, two fields were surveyed at random. In each field 20 plants were selected at five locations, four corners of the field and one at the centre to record the incidence and severity of powdery mildew, were fixed.

Per cent disease incidence for powdery mildew disease was calculated by using the following formula:

Number of infected plants

Per cent disease

Incidence $(\mathrm{PDI})=$-------------------------- $\times 100$

Total number of plants

The incidence and severity of powdery mildew were recorded mandal-wise. Powdery mildew severity was assessed by disease rating (AICRP, MULLaRP, 2013) (Table 1). 
The per cent disease index (PDI) was computed from the above scale by using the following formula (Wheeler, 1969).

$$
\begin{gathered}
\text { Sum of all the numerical ratings } \\
\text { PDI }=\text { - } \begin{array}{c}
\text { Number of observations } \times \\
\text { maximum disease grade }
\end{array}
\end{gathered}
$$

Influence of weather conditions on severity of powdery mildew in Urdbean

A trial was conducted to determine the influence of weather conditions on the severity of powdery mildew disease in blackgram. Highly susceptible blackgram cultivar PU 31 was planted in a bulk plot of $10 \times 10 \mathrm{~m}^{2}$ during rabi 2015-16 at Agricultural College Farm, Bapatla, Andhra Pradesh. The severity of powdery mildew disease was recorded at every five days interval from 35 DAS to one week prior to harvesting. Meteorological data such as rainfall, maximum temperature, minimum temperature, relative humidity at morning and evening hours and wind velocity was collected from the Meteorological Station located at Agricultural college farm, Bapatla. Correlation and regression analyses were conducted to determine the influence of weather conditions on the severity of powdery mildew disease in blackgram.

\section{Results and Discussion}

Survey for the incidence and severity of powdery mildew disease of Urdbean

In Guntur district, a total of 16 fields of eight villages viz., Kantheru, Ponnekalu, Kothapalem, Manchala, Vargani, Nagalupadu, Bhallupadu and Appapuram, belonging to four mandals viz., Tadikonda, Veticherukuru, Pedanandipadu and Kakumanu were surveyed in which PU 31, LBG 752, LBG 623 are being cultivated (Fig. 1). Age of the crop varied in different fields due to variation in dates of sowing. The crops were approximately 40- 60 DAS (Table 2). Since the age of the crop is one of the important factors for occurrence and development of powdery mildew. The results of the survey are presented based on an age of the crop as follows. In 40 days old crop the mean powdery mildew disease incidence was maximum in Kothapalem village $(57.76 \%)$ of Veticherukuru mandal followed by Kantheru village $(46.44 \%)$ of Tadikonda mandal and minimum in Bhallupadu village (3.43\%) of Kakumanu mandal followed by Vargani village $(3.67 \%)$ of Pedanandipadu mandal and severity was maximum in Kothapalem (51.32\%) followed by Ponnekalu village $(37.16 \%)$ of Tadikonda mandal and minimum in Bhallupadu (2.35\%) followed by Vargani $(5.73 \%)$ (Table 2).

In 60 days old crop the mean powdery mildew disease incidence was maximum in Kantheru (87.01\%) followed by Kothapalem $(83.10 \%)$ and minimum in Vargani $(21.91 \%)$ followed by Bhallupadu (39.94\%) and mean per cent disease index (severity) was maximum in Kantheru $(88.08 \%)$ followed by Kothapalem $(83.73 \%)$ and minimum in Vargani $(19.16 \%)$ followed by Bhallupadu (33.56\%) (Table 2 and Fig. 2). The mean disease incidence was in the range of $3.43 \%$ (Bhallupadu village at 40 DAS) to $87.01 \%$ (Kantheru village at 60 DAS) and severity was in the range of $2.35 \%$ (Bhallupadu village at $40 \mathrm{DAS}$ ) to $88.08 \%$ (Kantheru village at 60 DAS). Highest mean incidence and mean severity was recorded in Tadikonda mandal (81.83 \% and $80.76 \%$ respectively) and lowest (42.18\% and $37.16 \%$ ) in Pedanandipadu mandal. The variation in disease at various locations may be mainly due to cultivated variety, crop age and climatic factors and cultural practices.

Among the weeds species associated with urdbean fields viz., Euphorbia geniculate, Convolvulus arvensis, Sida cordifolia, Abutilon indicum, Acalypha indica, 
Achyranthes aspera, Andrographis paniculata, Crotalaria verrucosa, Celosia argentina, Digera arvensis, Cleome viscosa, Xanthium strumarium and Mimosa pudica etc. Euphorbia geniculate was found infected with powdery mildew disease in all the four mandals. Findings of Dinesh et al., (2010) reported that powdery mildew disease varied in different locations depending on the crop age. Nour (1958) reported that Euphorbia species were an alternate host for powdery mildew infection. Similarly, field bindweed (Convolvulus arvensis) is highly susceptible to powdery mildew infection as reported by Karkanis et al., (2012).

\section{Symptomology and morphology}

The infected leaf surface, petioles, stem and pods appeared as small, round, whitish, powder-like spots (Plate 2). Symptoms first appeared on crown leaves on shaded lower leaves and on leaf under surfaces. These white powdery colonies grew in size and cover both sides of the leaf, petioles and young stems. When disease progressed lower leaves showed and chlorosis, distortion and premature leaf fall due to infection of E. Polygoni. Severe infection of inflorescence was found to affect pod setting where as severe infection at later stages showed shrivelled and dried appearance to immature pods. The morphology of $E$. polygoni noted that the fungus produced amphigenous dirty white hyaline mycelium and barrel shaped conidia measuring $1.089 \mu \mathrm{m}$ $\times 0.7131 \mu \mathrm{m}$ at $40 \times$ magnification (Plate 1 ).

Effect of weather factors and age of the crop on powdery mildew severity

A correlation study was undertaken at Agricultural College, Bapatla to study the relationship between severity of powdery mildew disease with weather parameters and crop age. The mean data on the weather parameters viz. maximum temperature (max), minimum temperature $(\mathrm{min})\left({ }^{0} \mathrm{C}\right)$, morning relative humidity $(\mathrm{RH})(\%)$, evening relative humidity $(\mathrm{RH})(\%)$, wind speed $(\mathrm{kmph})$ and rainfall $(\mathrm{mm})$ was recorded from 20 DAS at five days interval upto 65 DAS on PU 31 during rabi 2015-2016 (Fig. 3).

The maximum temperature varied from 26.90 ${ }^{0} \mathrm{C}$ to $33.80{ }^{\circ} \mathrm{C}$, minimum temperature varied from $15.30{ }^{\circ} \mathrm{C}$ to $26.00{ }^{\circ} \mathrm{C}$. Relative humidity during morning and evening ranged from 87 to 93 per cent and 63 to 89 per cent, respectively. The disease severity ranged from 0 per cent to 90.85 per cent (Table 3 ).

Fig.1 Powdery mildew incidence at 40 and 60 DAS in urdbean in Guntur district during rabi 2015-16

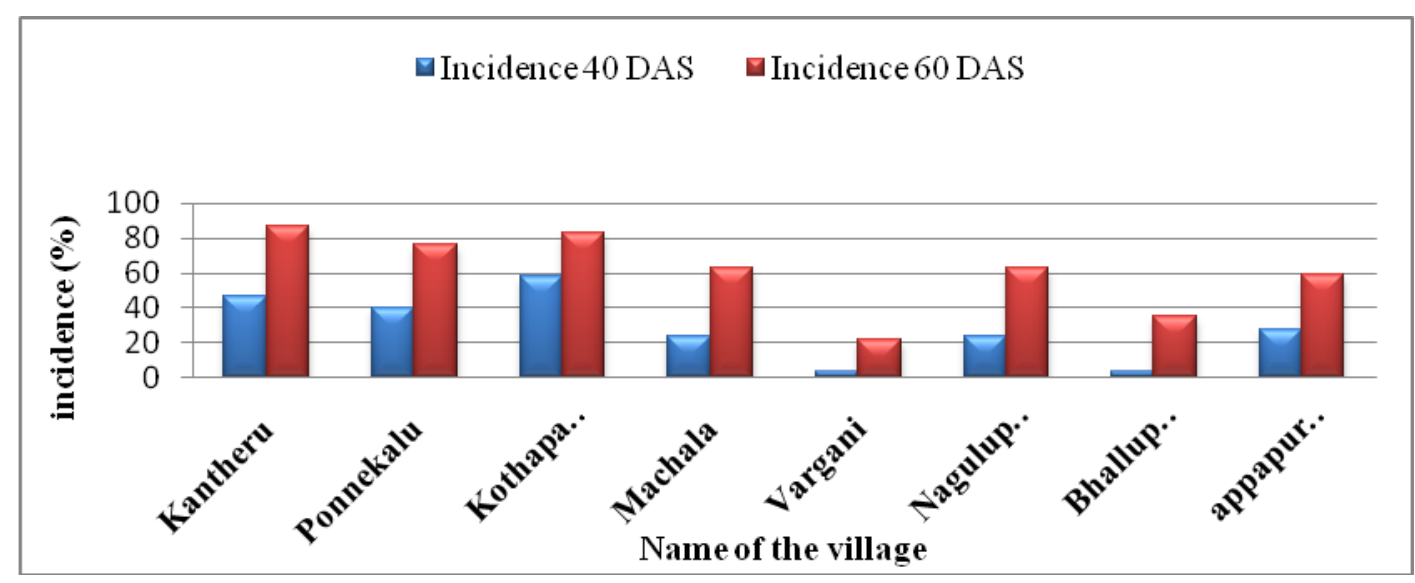


Fig.2 Powdery mildew severity at 40 and 60 DAS in urdbean in Guntur district during rabi 2015-16

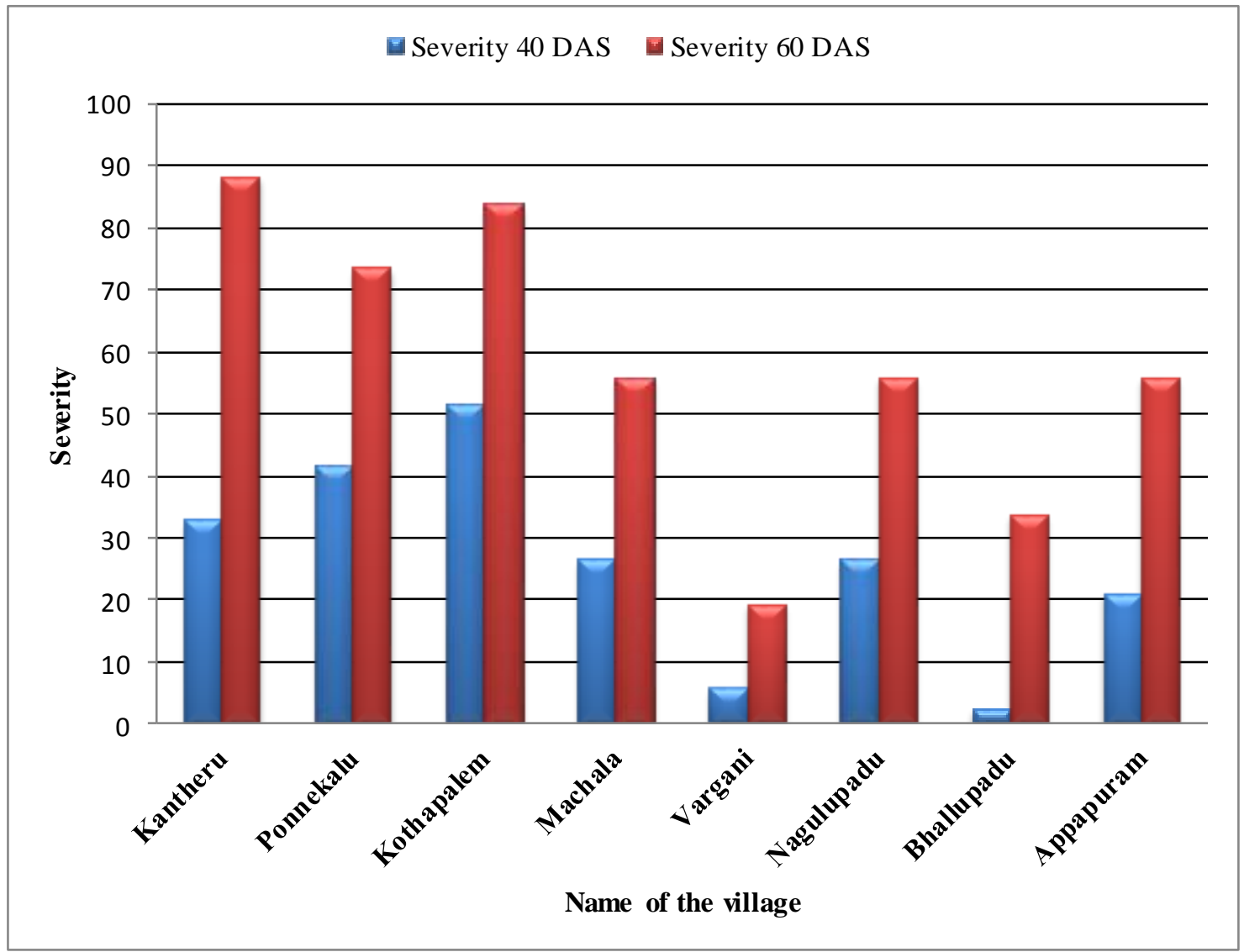

Plate.1 Morphology of fungus powdery mildew caused by Erysiphe polygoni (10X and 40X)

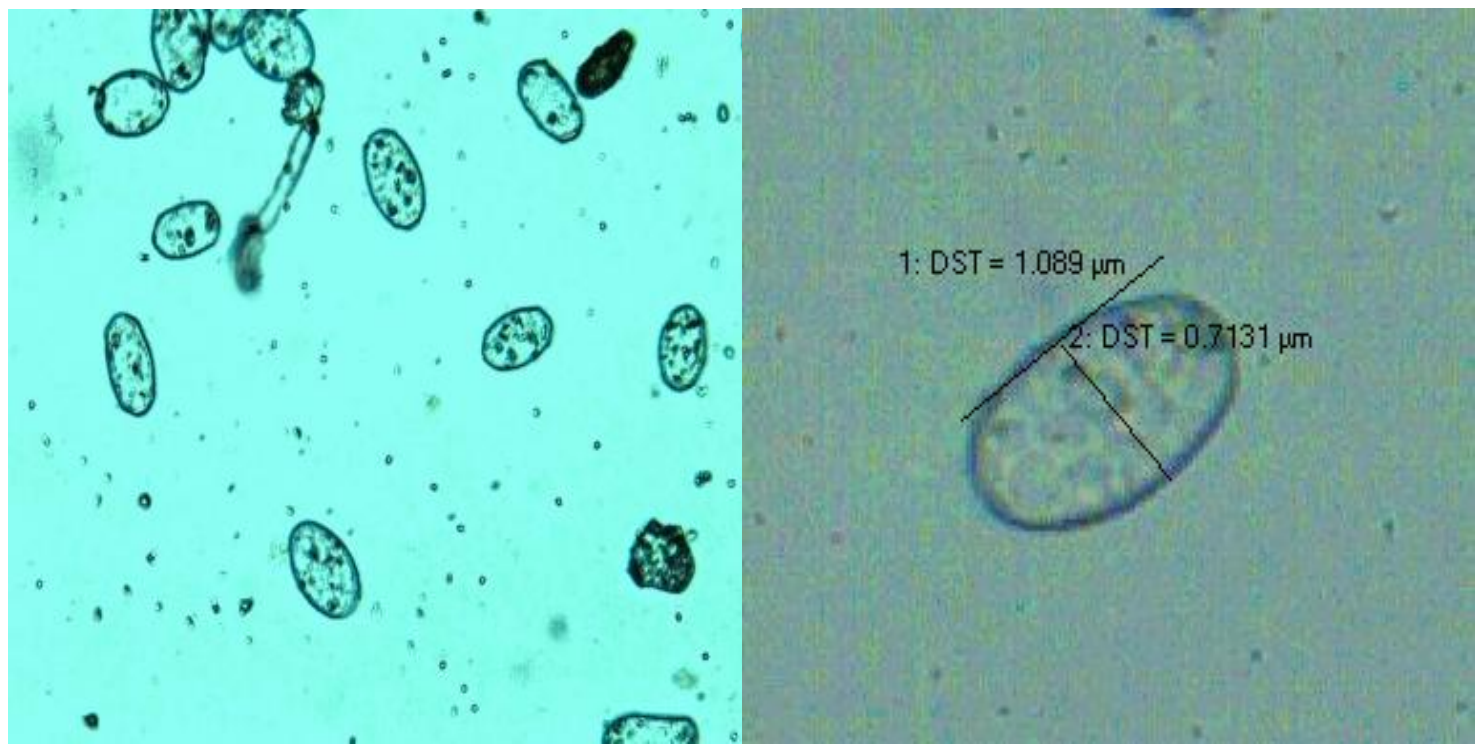


Plate.2 Symptoms of powdery mildew disease under field conditions

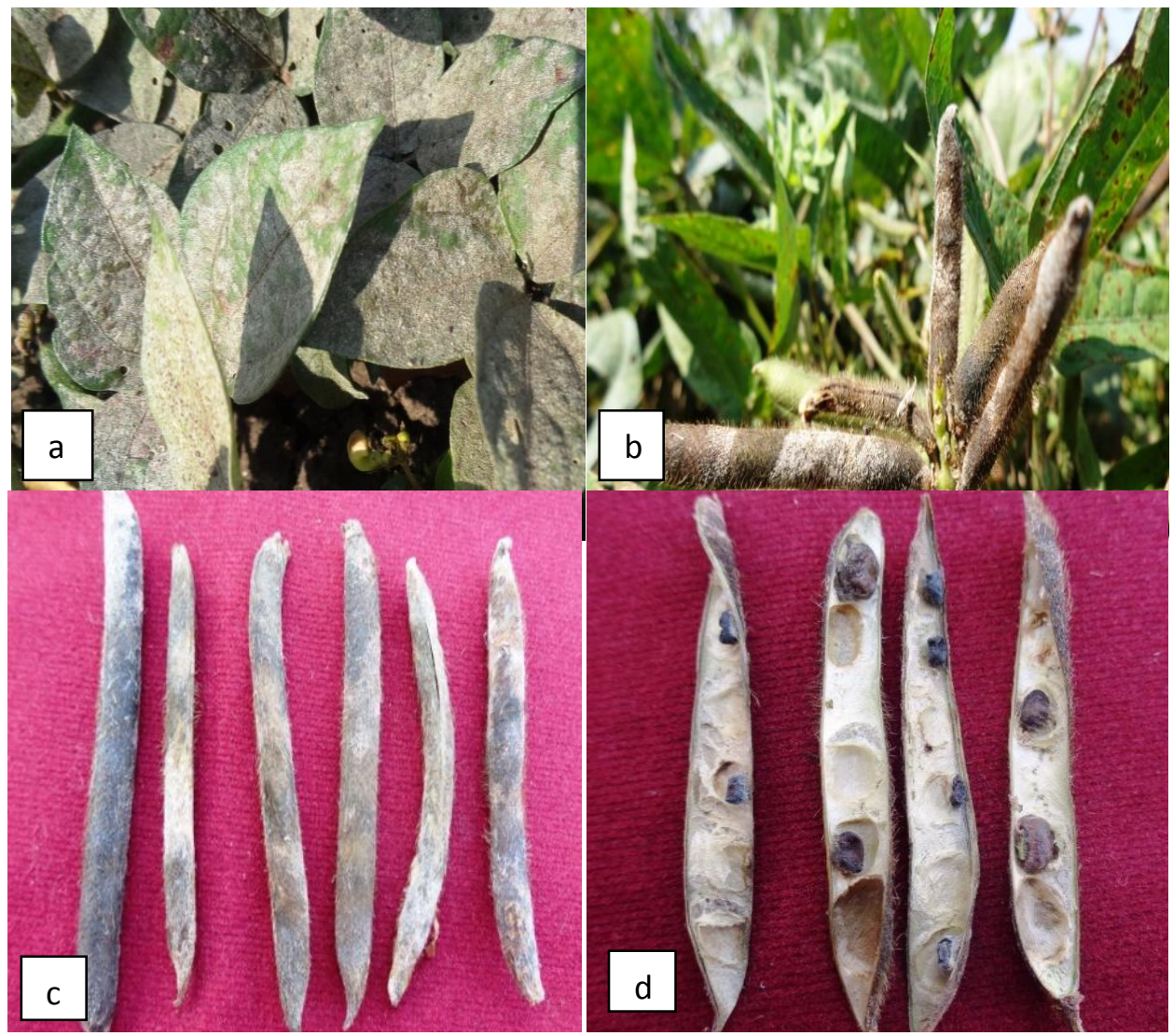

\section{Table.1 Modified MULLaRP scale (0-5)}

\begin{tabular}{|c|c|c|}
\hline Grade & Description & Reaction \\
\hline 0 & Plants free from infection on leaves, stems free from the disease & Free $(F)$ \\
\hline 1 & $\begin{array}{l}\text { Plants showing traces to } 10 \% \text { infection on leaves, stems free from the } \\
\text { disease }\end{array}$ & $\begin{array}{l}\text { Highly } \\
\text { Resistant } \\
\text { (HR) }\end{array}$ \\
\hline 2 & $\begin{array}{l}\text { Slight infection with thin coating of powdery growth on leaves } \\
\text { covering } 10.1-25 \% \text { leaf area, slight infection on stem and the pods } \\
\text { usually free }\end{array}$ & $\begin{array}{l}\text { Moderately } \\
\text { Resistant } \\
\text { (MR) }\end{array}$ \\
\hline 3 & $\begin{array}{l}\text { Dense powdery coating on leaves covering 25.1-50\% leaf area, } \\
\text { moderate infection on pods }\end{array}$ & $\begin{array}{l}\text { Moderately } \\
\text { Susceptible } \\
\text { (MS) }\end{array}$ \\
\hline 4 & $\begin{array}{l}\text { Dense powdery coating covering } 50.1-75 \% \text { leaf area, stems heavily } \\
\text { and pods moderately infected. Infected portion turns grayish. }\end{array}$ & $\begin{array}{l}\text { Susceptible } \\
\text { (S) }\end{array}$ \\
\hline 5 & $\begin{array}{l}\text { Severe infection with dense powdery growth covering } 75 \% \text { area of } \\
\text { the whole plant including pods, stems etc. resulting in premature } \\
\text { defoliation and drying. }\end{array}$ & $\begin{array}{l}\text { Highly } \\
\text { Susceptible } \\
\text { (S) }\end{array}$ \\
\hline
\end{tabular}


Int.J.Curr.Microbiol.App.Sci (2018) 7(11): 949-964

\section{Table.3 Powdery mildew severity and crop age in relation with weather variables during rabi, 2015-16}

\begin{tabular}{|c|c|c|c|}
\hline S. No. & Crop age & Date of observation & Severity \\
\hline $\mathbf{1}$ & 20 & $20-J a n$ & 0.00 \\
\hline $\mathbf{2}$ & 25 & $25-J a n$ & 0.00 \\
\hline $\mathbf{3}$ & 30 & $30-J a n$ & 0.00 \\
\hline $\mathbf{4}$ & 35 & $04-\mathrm{Feb}$ & 10.41 \\
\hline $\mathbf{5}$ & 40 & 09-Feb & 28.92 \\
\hline $\mathbf{6}$ & 45 & 14-Feb & 38.88 \\
\hline $\mathbf{7}$ & 50 & 19-Feb & 49.49 \\
\hline $\mathbf{8}$ & 55 & $24-\mathrm{Feb}$ & 71.60 \\
\hline $\mathbf{9}$ & 60 & 29-Feb & 85.61 \\
\hline $\mathbf{1 0}$ & 65 & $04-\mathrm{Mar}$ & 90.85 \\
\hline
\end{tabular}

Table.4 Correlation between powdery mildew disease severity and weather factors during rabi 2015-2016

\begin{tabular}{|c|c|c|}
\hline Sl. No. & Variable & $\begin{array}{l}\text { Correlation co- } \\
\text { efficient (r) }\end{array}$ \\
\hline 1 & Maximum temperature $\left({ }^{0} \mathrm{C}\right)$ & $0.657 *$ \\
\hline 2 & Minimum temperature $\left({ }^{0} \mathrm{C}\right)$ & 0.063 \\
\hline 3 & Relative humidity at 8.30 A.M (\%) & -0.355 \\
\hline 4 & Relative humidity at 5.30 P.M (\%) & -0.486 \\
\hline 5 & Rainfall (mm) & -0.405 \\
\hline$\overline{6}$ & Wind speed (Kmph) & -0.527 \\
\hline 7 & Crop age & $0.984 *$ \\
\hline at $5 \%$ & $r$ tab value $=2.306$ & \\
\hline
\end{tabular}


Table.2 Survey on the incidence and severity of powdery mildew disease in urdbean in Guntur district of A.P during rabi, 2015

\begin{tabular}{|c|c|c|c|c|c|c|c|c|c|c|c|c|}
\hline \multirow{2}{*}{$\begin{array}{l}\text { Sl. } \\
\text { No. }\end{array}$} & \multirow[t]{2}{*}{ Mandal } & \multirow{2}{*}{$\begin{array}{c}\text { Name of the } \\
\text { village }\end{array}$} & \multirow{2}{*}{$\begin{array}{c}\text { Date of } \\
\text { observation }\end{array}$} & \multirow{2}{*}{$\begin{array}{l}\text { Area } \\
\text { (in } \\
\text { acres) }\end{array}$} & \multirow[t]{2}{*}{ Variety } & \multirow{2}{*}{$\begin{array}{l}\text { Total } \\
\text { plants }\end{array}$} & \multicolumn{2}{|c|}{40 DAS } & \multicolumn{2}{|c|}{60 DAS } & \multirow{2}{*}{$\begin{array}{l}\text { Preceeding / } \\
\text { Surroundin } \\
\text { g crops }\end{array}$} & \multirow[t]{2}{*}{ Weed flora } \\
\hline & & & & & & & $\begin{array}{c}\text { Per cent } \\
\text { disease } \\
\text { incidence }\end{array}$ & PDI & $\begin{array}{l}\text { Per cent } \\
\text { Disease } \\
\text { incidence }\end{array}$ & PDI & & \\
\hline \multirow[t]{5}{*}{1} & \multirow[t]{5}{*}{ Tadikonda } & \multirow[t]{2}{*}{ Kantheru } & \multirow[t]{2}{*}{ 22-Oct } & 2 & $\begin{array}{l}\text { LBG } \\
623\end{array}$ & 106 & 45.51 & 26.28 & 87.14 & 86.92 & $\begin{array}{c}\text { Rice/ } \\
\text { Blackgram }\end{array}$ & $\begin{array}{l}\text { Euphorbia } \\
\text { geniculate, Sida } \\
\text { cordifolia }\end{array}$ \\
\hline & & & & 1 & $\begin{array}{c}\mathrm{LBG} \\
752\end{array}$ & 116 & 47.38 & 39.04 & 86.89 & 89.24 & $\begin{array}{c}\text { Rice/ } \\
\text { Blackgram }\end{array}$ & $\begin{array}{l}\text { Abutilon indicum, } \\
\text { Acalypha indica, } \\
\text { Achyranthes } \\
\text { aspera, } \\
\text { Andrographis } \\
\text { paniculata, } \\
\text { Euphorbia } \\
\text { geniculate }\end{array}$ \\
\hline & & $\begin{array}{l}\text { Village } \\
\text { Mean }\end{array}$ & & & & & 46.44 & 32.66 & 87.01 & 88.08 & & \\
\hline & & \multirow[t]{2}{*}{ Ponnekalu } & \multirow[t]{2}{*}{ 21-Oct } & 1.5 & PU 31 & 100 & 32.51 & 33.68 & 76.24 & 77.60 & $\begin{array}{c}\text { Rice/ } \\
\text { Blackgram }\end{array}$ & $\begin{array}{l}\text { Euphorbia } \\
\text { geniculate, } \\
\text { Crotalaria } \\
\text { verrucosa } \\
\text { Convolvulus } \\
\text { arvensis Celosia } \\
\text { argentina, Digera } \\
\text { arvensis, Cleome } \\
\text { viscosa, Xanthium } \\
\text { strumarium }\end{array}$ \\
\hline & & & & 2 & $\begin{array}{c}\mathrm{LBG} \\
752\end{array}$ & 100 & 47.87 & 49.64 & 77.09 & 69.28 & Rice/ Maize & $\begin{array}{l}\text { Abutilon indicum, } \\
\text { Acalypha indica, } \\
\text { Achyranthes aspera, } \\
\text { Crotalaria } \\
\text { verrucosa, } \\
\text { Celosia argentina, } \\
\text { Cleome viscosa, }\end{array}$ \\
\hline
\end{tabular}


Int.J.Curr.Microbiol.App.Sci (2018) 7(11): 949-964

\begin{tabular}{|c|c|c|c|c|c|c|c|c|c|c|c|c|}
\hline & & & & & & & & & & & & Sida cordifolia \\
\hline & & $\begin{array}{l}\text { Village } \\
\text { Mean }\end{array}$ & & & & & 40.19 & & 76.66 & \multicolumn{2}{|c|}{73.44} & \\
\hline & & $\begin{array}{c}\text { Mandal } \\
\text { mean }\end{array}$ & & & & & 43.31 & & 81.83 & \multicolumn{2}{|c|}{80.76} & \\
\hline 2 & \multirow[t]{7}{*}{ Veticherukuru } & \multirow[t]{2}{*}{ Kothapalem } & \multirow[t]{2}{*}{$28-\mathrm{Oct}$} & 3.5 & $\begin{array}{c}\text { LBG } \\
752\end{array}$ & 121 & 54.40 & 50.52 & 83.12 & 87.80 & Rice/ Blackgram & $\begin{array}{l}\text { Euphorbia } \\
\text { geniculate, } \\
\text { Crotalaria } \\
\text { verrucosa, } \\
\text { Celosia } \\
\text { argentina, }\end{array}$ \\
\hline & & & & 1 & $\begin{array}{c}\text { LBG } \\
752\end{array}$ & 100 & 61.13 & 52.12 & 83.08 & 79.67 & Rice/ Blackgram & $\begin{array}{l}\text { Sida cordifolia, } \\
\text { Xanthium } \\
\text { strumarium }\end{array}$ \\
\hline & & Village Mean & & & & & 57.76 & 51.32 & 83.10 & \multicolumn{2}{|l|}{83.73} & \\
\hline & & \multirow[t]{2}{*}{ Machala } & \multirow[t]{2}{*}{ 1-Nov } & 2 & PU 31 & 94 & 25.82 & 32.58 & 69.02 & 63.00 & Rice/ Blackgram & $\begin{array}{l}\text { Achyranthes } \\
\text { aspera, Sida } \\
\text { cordifolia, } \\
\text { Xanthium } \\
\text { strumarium }\end{array}$ \\
\hline & & & & 3 & PU 31 & 109 & 21.61 & 20.38 & 55.87 & 48.52 & Rice/ Blackgram & $\begin{array}{l}\text { Abutilon indicum, } \\
\text { Acalypha indica, } \\
\text { Convolvulus } \\
\text { arvensis } \\
\text { Achyranthes } \\
\text { aspera, } \\
\text { Cleome viscosa, } \\
\text { Sida cordifolia, } \\
\text { Xanthium } \\
\text { strumarium }\end{array}$ \\
\hline & & Village mean & & & & & 23.71 & 26.48 & 62.44 & \multicolumn{2}{|l|}{55.76} & \\
\hline & & Mandal Mean & & & & & 37.23 & 39.90 & 72.77 & \multicolumn{2}{|l|}{69.74} & \\
\hline
\end{tabular}




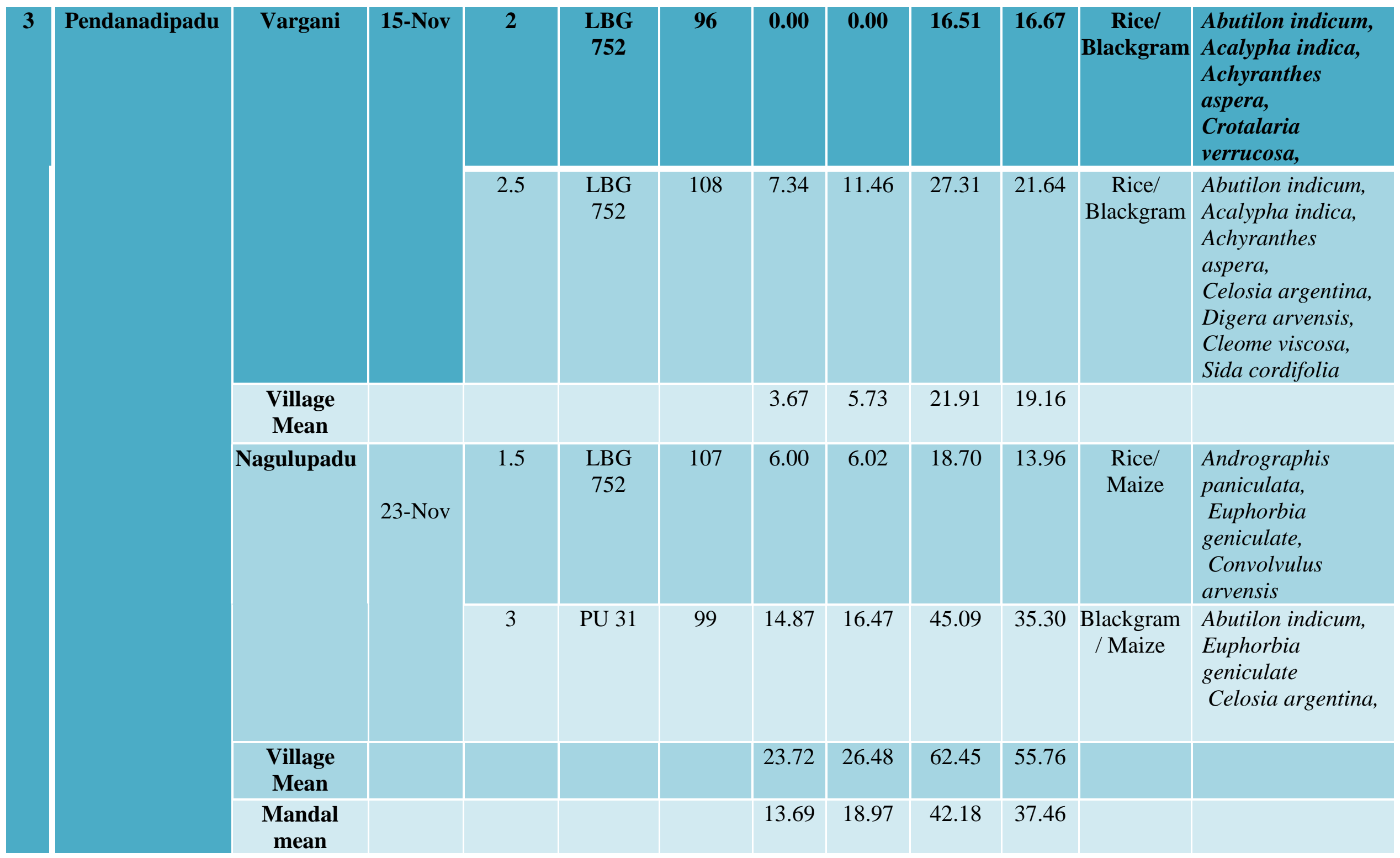




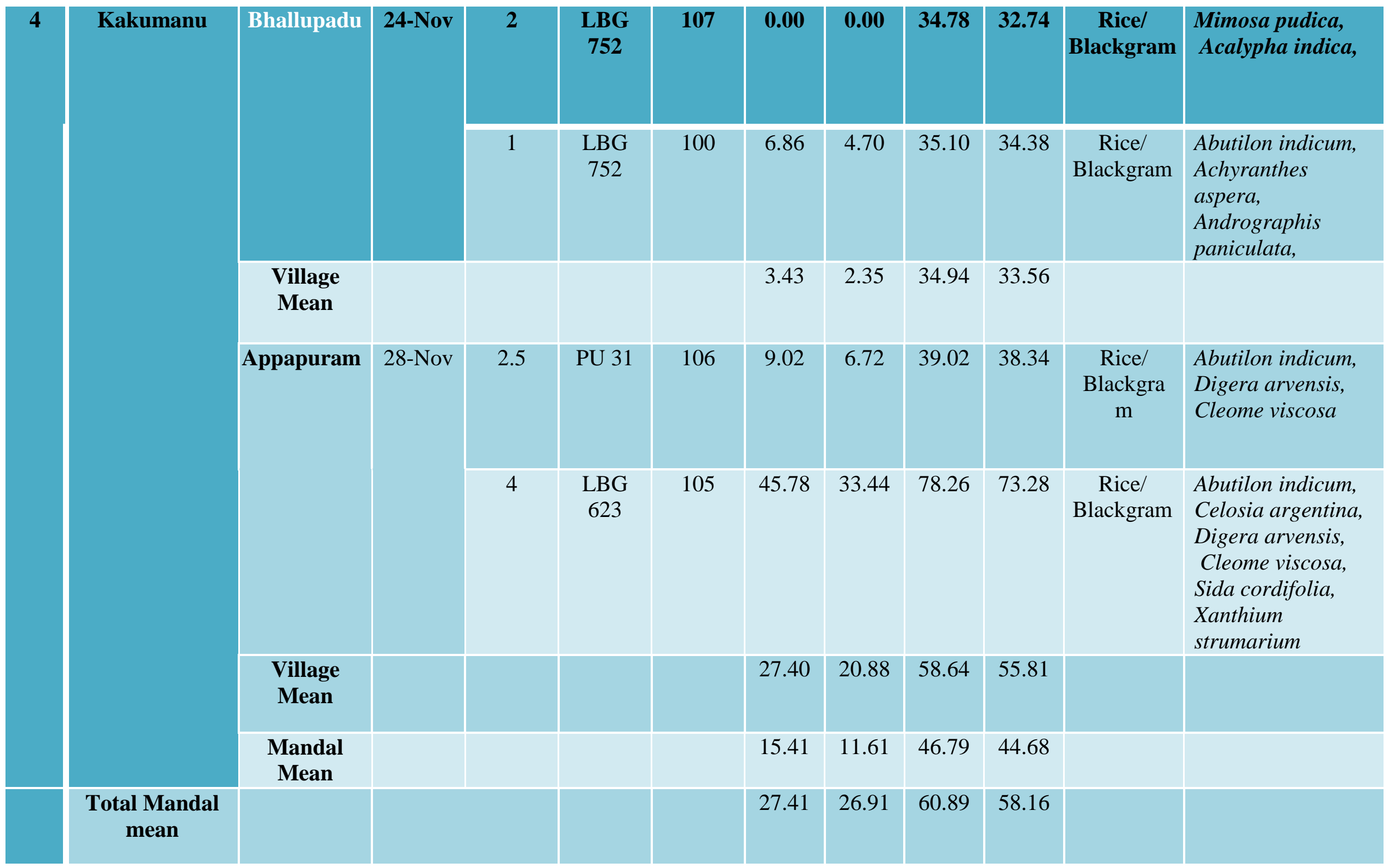


Table.5 Regression equations of certain weather variables on severity of powdery mildew disease during rabi 2015-16

\begin{tabular}{|c|c|c|c|c|}
\hline $\begin{array}{l}\text { Sl. } \\
\text { No. }\end{array}$ & Regression equations & F value & Standard error & $\mathbf{R}^{2}$ \\
\hline 1 & $y=-337.21+11.944 x_{1} *$ & 6.075 & 4.88 & 0.412 \\
\hline 2 & $y=-320.669+-11.708 \times 1 *+22.900 \times 2 *$ & 7.940 & 3.83 & 0.681 \\
\hline 3 & $y=-186.221+11.092 x_{1}+-22.611 x_{2}+-1.279 x_{3}$ & 4.540 & 4.00 & 0.701 \\
\hline 4 & $y=-279.80+10.017 x_{1} *+-35.57 x_{2} *+1.070 x_{3}+5.5803 x_{4} *$ & 9.290 & 15.98 & 0.866 \\
\hline 5 & $y=-102.369+-8.025 x_{1}+10.280 x_{2}+-0.657 x_{3}+-0.970 x_{4}+3.383 x_{5}^{*}$ & 211.82 & 3.137 & 0.891 \\
\hline 6 & $y=180.478+-9.317 x_{1} *+13.349 x_{2}+0.400 x_{3}+-0.484 x_{4}+3.420 x_{5} *+-0.399 x_{6}$ & 243.33 & 2.67 & 0.990 \\
\hline 7 & $\begin{array}{l}y=-568.65+-24.0 x_{1}+34.534 x_{2}+1.760 x_{3}+-1.751 x_{4}+4.542 x_{5}+-1.052 x_{6}+- \\
4558.346 .2 x_{7}\end{array}$ & 211.88 & 2.65 & 0.991 \\
\hline
\end{tabular}

\begin{tabular}{|c|c|c|c|c|c|}
\hline $\begin{array}{l}\text { S. } \\
\text { No. }\end{array}$ & Variables & \multicolumn{2}{|c|}{$\begin{array}{c}\text { Partial regression } \\
\text { Coefficients (b) }\end{array}$} & Standard Error (E) & P value \\
\hline 1 & Maximum temperature & \multicolumn{2}{|l|}{$10.017 *$} & 3.173 & 0.025 \\
\hline 2 & Wind speed & \multicolumn{2}{|l|}{$-35.577 *$} & 8.203 & 0.007 \\
\hline 3 & RH (8.30 am) & \multicolumn{2}{|l|}{-1.0705} & 2.747 & 0.713 \\
\hline 4 & Minimum temperature & \multicolumn{2}{|l|}{$5.5803 *$} & 1.986 & 0.038 \\
\hline \multicolumn{2}{|c|}{$*$ Significant at $p \leq 0.05$} & Intercept $(a)=-279.193$ & \multicolumn{2}{|l|}{$\mathrm{N}=10$} & \\
\hline \multicolumn{2}{|c|}{$\begin{array}{l}\mathrm{X}_{1 \text { = }} \text { Maximum } \\
\text { temperature }\end{array}$} & $\mathrm{X}_{2}=\mathrm{Wind}$ speed & \multicolumn{2}{|c|}{$\begin{array}{l}\mathrm{X}_{3}=\text { Relative humidity }(8.30 \\
\text { am })\end{array}$} & $\begin{array}{l}\mathrm{X}_{4}=\text { Minimum } \\
\text { temperature }\end{array}$ \\
\hline \multicolumn{2}{|c|}{$X_{5}=$ Crop age } & $\begin{array}{l}\mathrm{X}_{6}=\text { Relative humidity }(5.30 \\
\mathrm{am})\end{array}$ & \multicolumn{2}{|c|}{$\mathrm{X}_{7}=$ Rainfall $(\mathrm{mm})$} & \\
\hline
\end{tabular}


Fig.3 Powdery mildew severity in relation to weather parameter s and crop age factors during rabi, 2015-16

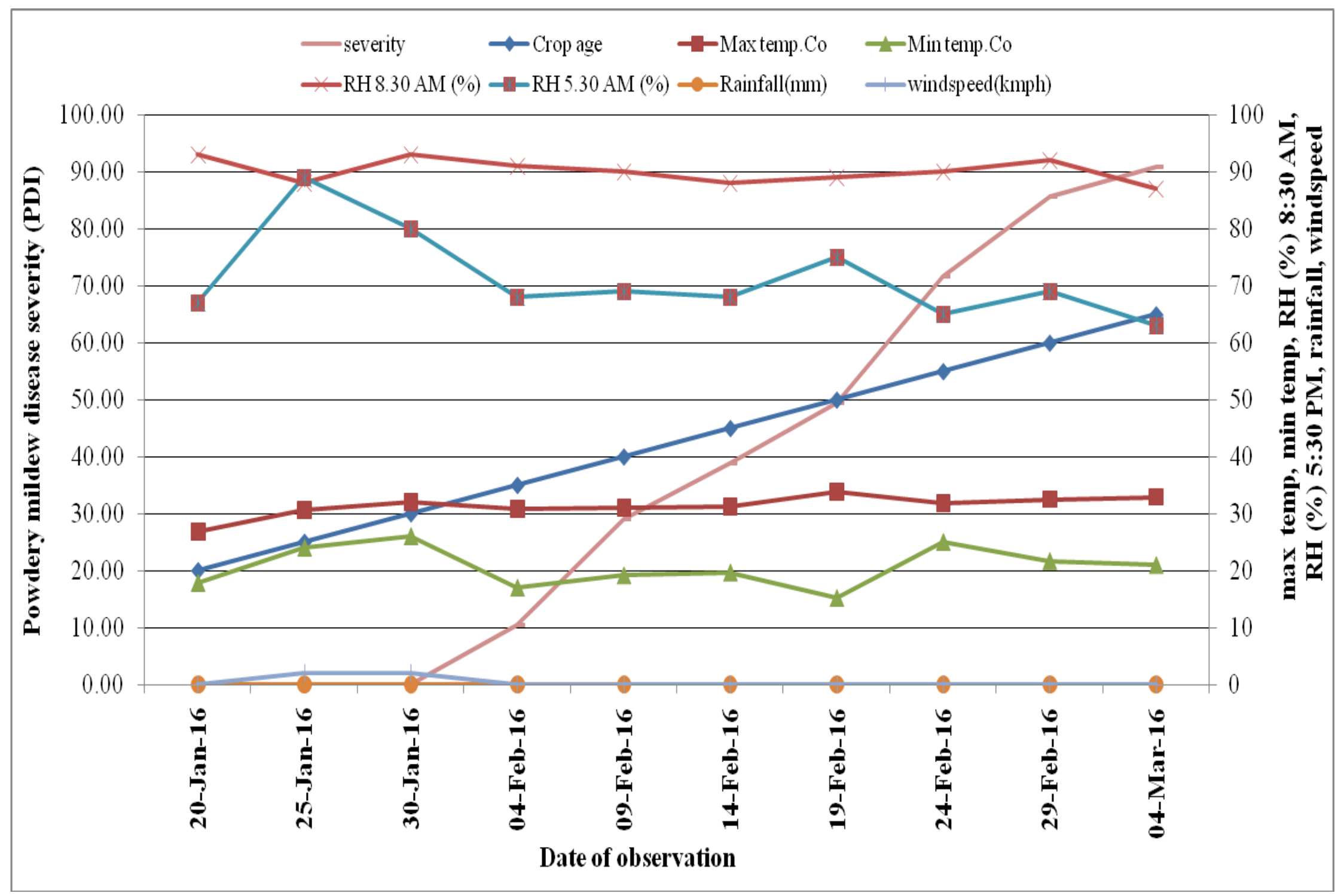


The severity had a high significant positive correlation with crop age $(r=0.984)$ and maximum temperature $(\mathrm{r}=0.657)$. Nonsignificant correlation was observed between severity and rest of the independent variables (Table 4). These observations are in agreement with the findings of Thakur and Agarwal (1995); Solanki et al., 1999; Yarwood (1957); Bhattacharya and Shukla, 2002; Gupta and Sharma, 2009 and Kanzaria et al., 2013. The maximum temperature during the period of occurrence of powdery mildew up to last observation on severity was in the range of $30.90^{\circ} \mathrm{C}-33.80^{\circ} \mathrm{C}$ ) and is well within the favourable range of $28{ }^{0} \mathrm{C}-36{ }^{0} \mathrm{C}$ for powdery mildew (Delp, 1954; Schnathorst, 1960; Manners et al., 1963). Hence, the maximum temperature showed a strong positive influence on powdery mildew severity.

Regression analysis with performed by powdery mildew severity as dependent variable and maximum temperature, minimum temperature, morning relative humidity, evening relative humidity, rainfall, wind speed and crop age as independent variables to find out the best fit multiple regression equation by using the coefficients of determination $\left(R^{2}\right)$.Stepwise multiple regression analysis was performed using the following equation:

$\begin{array}{llc}y & =b o \quad+\quad b_{1} x_{1} \\ b_{3} x_{3} \ldots \ldots \ldots \ldots \ldots \ldots \ldots \ldots \ldots+b_{n} x_{n}\end{array}+b_{2} x_{2}+$

Where $\mathrm{y}=$ per cent disease index, $b_{o}=$ intercept, $\quad b_{1}, \quad b_{2} \ldots \ldots . b_{n}=$ regression coefficient, and $\mathrm{x}_{1}, \mathrm{x}_{2}, \ldots \ldots \ldots \ldots \ldots \ldots \mathrm{x}_{\mathrm{n}}=$ independent variables. The results were presented in the Table 4.

Multiple regression analysis yielded seven distinct equations with $R^{2}$ values ranging from 0.991 to $0.412(\mathrm{P}<0.05)$. However, the best fit equation was obtained in maximum temperature, wind speed, RH (8.30 am), minimum temperature as independent variables (equation 4).

$\mathrm{Y}=-279.80+10.017(\max t e m p)^{*}+-$ 35.57 (wind speed)*+1.070 (RH morning) $+5.5803(\min \text { temp })^{*}$

$\mathrm{N}=10 R^{2}=0.86 \mathrm{~F}$ value $=9.29$ Standard error $=15.98$

* Significant at 5\% level

The best fit equation showed 86.6 per cent role of tested independent variables on powdery mildew severity (Table 5). Results were in accordance with the reports of earlier workers (Solanki et al., 1999; Bhattacharya and Shukla, 2002; Gadre et al., 2002; Gupta and Sharma, 2009; Kanzaria et al., 2013). Similarly, maximum and minimum temperature was favourable for disease development as reported by earlier findings (Yarwood et al., 1957). Wind speed effected an instantaneous dispersal of conidia of Erysiphe polygoni which was reported by Hammett and Manners (1974).

\section{Acknowledgement}

Authors are grateful to Heads, Department of Plant Pathology, Regional Agricultural Research Station, Lam, Guntur District, Agricultural College Farm for providing the necessary facilities to undertake this work.

\section{References}

Abbaiah, K. 1993. Development of powdery mildew epidemics in urdbean in relation to weather factors. Indian Journal of Pulse Research. 6: 186-188.

All India Coordinated Research Project on MULLaRP. 2013. Proceedings and Recommendations Indian Institute of 
Pulses Research, Kanpur. www.aicrpmullarp.res.in.

Arora et al., 1989. Record from Proseabase. van der Maesen, L. J. G., Somaatmadja, S. (Eds). PROSEA (Plant Resources of South-East Asia) Foundation, Bogor, Indonesia.

Baligar, V. C., Fageria, N. K., 2007. Agronomy and physiology of tropical cover crops. J. Plant Nutr, 30 (8): 12871339

Bhattacharya, A and Shukla, P. 2002. Effect of environment factors on powdery mildew in field pea under irrigated and rainfed conditions. Indian Journal of Agricultural Research. 36: 149-155.

CRN India, 2011. Urad. CRN India

Delp, C.J. 1954. Effect of temperature and humidity on grape powdery mildew fungus. Phytopathology. 44: 26.

Department of Agriculture and Cooperation, Government of A.P. 2013. Area and production of agricultural crops in Andhra Pradesh. www.agri.ap.nic.in.

Department of Agriculture and Cooperation, Government of India. 2012. Area and production of agricultural crops in India. www.agricoop.nic.in.

Dinesh, M.B., Kulkarni, S., Harlapur, I.S., Benagi, I.V and Mallapur, P.C. 2010. Prevalence of powdery mildew in sunflower growing areas in northern Karnataka. Karnataka Journal of Agricultural Sciences. 23: 521-523.

Göhl, B., 1982. Les aliments du bétail sous les tropiques. FAO, Division de Production et Santé Animale, Roma, Italy.

Gupta, M and Sharma, S.K. 2009. Epidemiology and management of powdery mildew of apple in nurseries. Biological Forum. 20: 12 -17.

Hammett, K.R.W and Manners, J.G. 1974. Conidium liberation in Erysiphe graminis. III. Wind tunnel studies.
Transaction British Mycological Society. 2: 267-282.

Jansen, P. C. M., 2006. Vigna mungo (L.) Hepper. Record from Protabase. Brink, M. and Belay, G. (Editors). PROTA (Plant Resources of Tropical Africa / Ressources végétales de l' Afrique tropicale), Wageningen, Netherlands.

Kanzaria, K.K., Dhruj, I.U and Sahu, D.D. 2013. Influence of weather parameters on powdery mildew disease of mustard under North Saurashtra Agroclimatic Zone. Journal of Agrometerology.15: 86-88.

Karkanis, A., Bilalis, D., Efthimiadou, A and Katsenios, A. 2012. Effects of field bindweed (Convolvulus arvensis L.) and powdery mildew [Leveillula taurica (Lev.) Arn.] on pepper growth and yield. Horticultural science. 39: 135138.

Kiss*, L and Szentivanyi, O. 2001. Infection of bean with cucumber powdery mildew, Podosphaera fusca. New Disease Reporter. 50: 411.

Legapsi, B.M., Capiton, E.M and Hubbell, J.N. 1978. AVRDC. Phillipines, programme studies. First International Symposium on Mungbean. 220-223.

Manners, J.G and Hossain, S.M.M. 1963. Effects of temperature and humidity on conidia germination in Erysiphe cichoracearum. Transactions of the British Mycological Society. 46: 225234.

Nene, Y.L. 1972. A survey of the viral diseases of pulse crops in Uttar Pradesh. First Annual Report. FG-IN-358, Uttar Pradesh Agricultural University. 1-25.

Nour, M.A. Studies on Leveillula taurica (Lev.) Arn. and other powdery mildews. Transactions of the British Mycological Society. 41: 17-38.

Schnathrost, W.C. 1960. Effects of temperature and moisture stress on 
lettuce powdery mildew of the fungus. Phytopathology.50: 380.

Sharma, O. P., Bambawale, O. M., Gopali, J. B., Bhagat, S., Yelshetty, S., Singh, S. K., Anand, R., Singh, O.M., 2011. Field guide Mung bean and Urd bean. Government of India, Department of agricultural and co-operation, NCIPM, ICAR, New Delhi, India.

Solanki, V.A., Patel, B.K and Shekh, A.M. 1999. Meterological variables in relation to an epiphytotic of powdery mildew disease of mustard. Indian Phytopathology. 52: 138-141.

Thakur, M.P and Agarwal, K.C. 1995. Epidemiological studies on powdery mildew of mungbean and urdbean. International Journal of Pest Management. 41: 146-153.

Wheeler, B.E.J. 1969. An Introduction to Plant Diseases. John Wiley, London. 301.

Yarwood, C.E. 1957. Powdery mildews. Botanical Review. 23: 235.

Yoganandhan, K., Hameed, A. S. S., 2000. Evaluation of red gram, Cajanus cajan, and black gram, Vigna mungo, husks as food for brine shrimp, Artemia sp., culture. J. Appl. Aquacult., 10 (2): 7985.

\section{How to cite this article:}

Tulasi Korra and Manoj Kumar, V. 2018. Survey for the Occurrence of Powdery Mildew and It's Effect of Weather Factors on Severity of Powdery Mildew in Guntur District. Int.J.Curr.Microbiol.App.Sci. 7(11): 949-964. doi: https://doi.org/10.20546/ijcmas.2018.711.111 